\title{
Impact of foliar spraying with iron and magnesium on growth, yield, chemical constituents and storability of broccoli
}

\author{
Amal S.H. Atress and Omaima O. Mohamed \\ Postharvest and Handling of Vegetable Crops Department, Horticulture Research Institute, Agriculture \\ Research Center, Giza, Egypt.
}

\begin{abstract}
This study were carried out during the winter season of 2012/2013 and 2013/2014 at the Agriculture Research Farm, El-Kassasien Hort. Res. Station, Ismalia Governorate, Egypt, in sandy texture soil and the laboratory of the vegetable handling department, to study the effect of foliar spray with iron $(\mathrm{Fe})$ and magnesium (Mg) i.e. Fe at 50 and $100 \mathrm{ppm}, \mathrm{Mg}$ at 0.5 and $1.0 \%, \mathrm{Fe}$ at $50 \mathrm{ppm}+\mathrm{Mg}$ at $0.5 \%, \mathrm{Fe}$ at $50 \mathrm{ppm}+$ $\mathrm{Mg}$ at $1.0 \%$, Fe at $100 \mathrm{ppm}+\mathrm{Mg}$ at $0.5 \%$ and $\mathrm{Fe}$ at $100 \mathrm{ppm}+\mathrm{Mg}$ at $1.0 \%$ as well as the Control on growth, yield, chemical constituents, and storability of broccoli Sakura $\mathrm{F}_{1}$ hybrid (Brassica oleracea var. italica), grown under sandy soil conditions using drip irrigation system. Spraying broccoli plants with $\mathrm{Fe}$ at $100 \mathrm{ppm}$ plus $\mathrm{Mg}$ at $0.5 \%$ or $1.0 \%$ significantly increased all the studied vegetative growth traits compared with other tested treatments with non significant differences between them. Significant increases in the yield and its components and chemical constituents of broccoli florets [Fe ( $\mathrm{ppm}), \mathrm{Mg}(\mathrm{ppm})$, nitrogen and protein \%] were recorded by foliar application of $\mathrm{Fe}$ at $100 \mathrm{ppm}$ plus $\mathrm{Mg}$ at $0.5 \%$ or $1.0 \%$ with non significant differences between them. Regarding quality parameters of broccoli florets during storage at $5^{\circ} \mathrm{C}$ and $90-95 \% \mathrm{RH}$ for 15 days, results showed that visual appearance, ascorbic acid content and external color of broccoli florets were decreased as the storage period increased. Broccoli florets obtained from plants treated with $\mathrm{Fe}$ at $100 \mathrm{ppm}$ plus $\mathrm{Mg}$ at $0.5 \%$ or $1.0 \%$ exhibited acceptable appearance, fresh green color florets and higher ascorbic acid (vit. C.) content during storage as compared with the control or other treatments.
\end{abstract}

Key words: broccoli, magnesium, iron, yield, chemical constituents, storage.

\section{Introduction}

Broccoli (Brassica oleracea var. italica) is a vegetable with high nutritional value and sometimes referred to as the crown jewel of nutrition due to its low caloric content, high dietary fiber and ascorbic acid levels and wide range of anticarcinogenic and antioxidant compounds (King and Morris, 1994a, and Schouten et al., 2009). In Egypt, broccoli is one of the promising vegetable crops for exportation. Broccoli florets produced in high quality especially in the winter season, where the agricultural products exportation to European markets was increase. Broccoli still grown in a very limited scattered areas and the total cultivated area is not exactly known (Tolba, 2005). Recently slight increased attentions towards extending the devoted cultivated areas and increasing the production of some untraditional vegetable crops including broccoli, through the pathway of nutrition for local consumption and early exportation, have been directed ( Gad and Abd ElMoez 2011).

Harvested broccoli consists of hundred of immature floral buds and thick fleshy flower branchlets attached to the central plant stem, which is collectively named the head. Harvesting broccoli florets causes a series of stresses to broccoli including wounding, separation from nutrient and hormone source, and dehydration. So, harvested broccoli becomes unable to maintain metabolic homeostasis and senescence rapidly. (Huber, 1987,
King and Morris, 1994a, b; Rushing, 1990; Tian et al., 1994). Broccoli shelf life is mainly determined by external appearance and surface color. Techniques utilized to maintain commercial and nutritional quality of broccoli florets usually imply postharvest treatments (Hasperue et al., 2011). However, very little attention has been given to preharvest factors, which could affect post harvest life.

Magnesium ( $\mathrm{Mg}$ ) is an essential nutrient for plant growth and plays an important role in many plant physiological processes such as photosynthesis $(\mathrm{Mg}$ is the central element of the chlorophyll molecule), sugar synthesis, starch translocation, formation of plant oils and fats, control of nutrient uptake, increase iron utilization and aid nitrogen fixation in legume nodules. It also works as an enzyme activator, a constituent of many enzymes and a carrier of phosphorus in the plant (Mengel and Kirkby 1987, Marschner 1995, Allison et al., 2001).

Several studies have been dealing with the role of $\mathrm{Mg}$ on vegetable crops, $\mathrm{Mg}$ as a foliar application significantly enhanced fresh weight, plant height, total and marketable curds yield and chemical composition of cauliflower leaves and curds (Ahmed et al., 2011). Foliar spray with $\mathrm{Mg}$ at 0.5 or $1.0(\mathrm{~g} / \mathrm{\ell})$ led to a significant increase in plant growth parameters, total yield and potassium $\%$ as well as Magnesium \% content in snow pea pods (Darwesh and Atress 2011). Spraying snap bean plants with $\mathrm{Mg}$ at $0.2 \%$ significantly increased number of branches per plant, N, P and $\mathrm{K}$ total uptake by plant, number 
of pods per plant and total yield per feddan (Mohammed et al., 2009).

Iron $(\mathrm{Fe})$ is a factor for approximately 140enzymes that catalyze unique biochemical reactions (Brittenham, 1994). Iron is critical for chlorophyll formation and photosynthesis and is important in the enzyme systems and respiration of plants (Havlin et al., 1999). Lashkari et al., 2007 reported that leaf area and marketable yield of cauliflower were found significantly highest with combined foliar spray of zinc and iron at $0.5 \%$ concentration each. Spraying pea plants with $\mathrm{Fe}$ at $100 \mathrm{ppm}$ gave the highest values of growth characters, green pods yield per feddan and $\mathrm{P}$ content in seeds (Mansour et al., 2012). Spraying broad bean plants with $\mathrm{Fe}$ at $500 \mathrm{ppm}$ increased plant height, pod length and yield per plant (El-Tantawy and Mahmoud 2013), foliar spraying of broad plants with $\mathrm{Fe}$ at500 ppm significantly increased chlorophyll a, b and total chlorophyll as well as yield and its components (El-Tantawy and Nawar 2013) . Kazemi, (2014) found that spraying strawberry plants with Fe at $1000 \mathrm{mg} / \boldsymbol{\ell}$ improved weight of primary and secondary fruits.

The objective of this work was to study the effect of iron and magnesium on the productivity and shelf life of broccoli florets.

\section{Materials and Methods}

\section{The field experiment:}

This field experiment was carried out during the winter season of 2012/2013 and 2013/2014 at the Agriculture Research Farm, El-Kassasien Hort. Res. Station, Ismalia Governorate, Egypt, to study the effect of foliar spray with iron and magnesium on growth, yield and chemical constituents of broccoli. The physical and chemical properties of the experimental soil field are presented in Table 1 according to Chapman and Pratt (1982).

Table 1. Physical properties and chemical analysis of the experimental soil (average two seasons).

\begin{tabular}{|c|c|}
\hline Soil parameter & Values \\
\hline Physical properties (\%) & \\
\hline Sand & 84.8 \\
\hline Silt & 8.5 \\
\hline Clay & 6.7 \\
\hline Texture & sandy \\
\hline Chemical properties & \\
\hline Organic matter $(\%)$ & 0.29 \\
\hline $\mathrm{PH}$ & 7.8 \\
\hline Available N $\quad(p p m)$ & 21.4 \\
\hline Available P $\quad$ (ppm) & 4.9 \\
\hline Available K （ppm) & 119.3 \\
\hline Calcium carbonate $(\%)$ & 3.97 \\
\hline $\mathrm{Mg}(\mathrm{ppm})$ & 9.4 \\
\hline $\mathrm{Fe}(\mathrm{ppm})$ & 3.9 \\
\hline
\end{tabular}

Soil sample was taken from $25 \mathrm{~cm}$ soil surface.
Seeds of broccoli Sakura $\mathrm{F}_{1}$ hybrid (Brassica oleracea var. italica) Tokita seed Co., LTD. Saitama, Japan.were sown at the nursery on $20^{\text {th }}$ and $24^{\text {th }}$ of September in 2012 and 2013 seasons, respectively. Seedlings were transplanted on $30^{\text {th }}$ and $4^{\text {th }}$ of October and November in 2012 and 2013 seasons, respectively, in the permanent field on one side of dripper lines at $40 \mathrm{~cm}$ between plants. One dripper line $\left(4.2 \mathrm{~m}^{2}\right)$ was used to measure vegetative growth traits and the other two dripper lines $\left(8.4 \mathrm{~m}^{2}\right)$ were used for estimating yield and its components. One dripper line was left between each two experimental units without spraying as a guard row to avoid the overlapping of spraying solutions. The plot area was $12.6 \mathrm{~m}^{2}$ every plot consisted of 3 rows $6 \mathrm{~m}$ in length and $70 \mathrm{~cm}$ in width with about 48 plants in every plot. The foliar application treatments i.e. Iron $(\mathrm{Fe})$ at 50 and $100 \mathrm{ppm}$, Magnesium $(\mathrm{Mg})$ at 0.5 and $1.0 \%$, $\mathrm{Fe}$ at $50 \mathrm{ppm}+\mathrm{Mg}$ at $0.5 \%, \mathrm{Fe}$ at $50 \mathrm{ppm}+\mathrm{Mg}$ at $1.0 \%, \mathrm{Fe}$ at $100 \mathrm{ppm}+\mathrm{Mg}$ at $0.5 \%$ and $\mathrm{Fe}$ at 100 $\mathrm{ppm}+\mathrm{Mg}$ at $1.0 \%$ as well as the Control (sprayed with tap water), were sprayed three times during the growth period of broccoli plants at 45, 60 and 75 days after transplanting. Each experimental unit received $2 \ell$ of solution for each level and using spreading agent (super film $1 \mathrm{ml} / \ell$ ) in all treatments. The untreated plants (check) were sprayed with tap water with spreading agent. The source of Iron was ferrous sulphate $\left(\mathrm{FeSO}_{4}\right)$, while the source of Magnesium was Magnesium sulphate $\left(\mathrm{MgSO}_{4}\right)$ and they obtained from El-Gomhouria Co. for trading medicines, chemicals and medical appliances, Sharkia Governorate, Zagazig, Egypt. The normal agriculture practices of broccoli under drip irrigation system were followed according to the recommendations of Ministry of Agriculture. The treatments were distributed in a randomized complete block design with three replications.

\section{The data were recorded as follow:}

Morphological characters: A random sample of three plants from each experimental unit was taken at harvesting time (100days from transplanting) to investigate growth parameters i.e., plant height $(\mathrm{cm})$, number of leaves/plant, total fresh weight (leaves + stem)/plant (g).

Yield and its components: At harvesting time, first week of January, (100 days from transplanting) broccoli florets were picked weekly through the harvesting period till the end of season for estimation of yield parameters: diameter of main floret $(\mathrm{cm})$, length of main floret $(\mathrm{cm})$, average weight of florets (g) and yield of broccoli florets (ton/fed.).

Photosynthetic pigments: Chlorophyll reading was measured at harvest stage in fresh leaves by using Minolta chlorophyll meter SPAD-501as SPAD units. 
Chemical constituents of florets: Previously taken sample of florets at harvest were oven dried and ground and wet digested with sulphuric acid and perchloric acid (3:1). Total nitrogen was determined according to the methods described by Bremner and Mulvaney (1982). Total Mg was estimated Flamephotometrically using Ienway Flame-photometer model Corning 400 according to Peterburgski; 1968. Total $\mathrm{Fe}$ was estimated using atomic absorption spectrophotometer (A Perkin-Elmer, Model 2380.usa) according to the methods of Chapman and Pratt (1982).

Total crude protein \%: It was calculated by multiplying total nitrogen $\times 6.25$.

Statistical analysis: All obtained data were subjected to the proper statistical analysis using the MSTAT statistical software and the treatments means were compared by using the LSD at 0.05 level of probability as described by Snedecor and Cochran (1980) and the differences among treatments were compared using Duncan's multiple range test (Duncan, 1958).

\section{The storage experiment:}

This experiment was conducted at the laboratory of the vegetable handling department to study the effect of spraying iron and magnesium at different rates and its combinations on maintaining quality of broccoli florets during storage. In this experiment, fresh broccoli florets which obtained from the previous field experiment were transported to the laboratory within two hours of harvest and kept overnight at $5^{\circ} \mathrm{C}$ and $90-95 \%$ relative humidity ( $\left.\mathrm{RH}\right)$. The following morning, the uniform and marketable florets were used from the all previous field treatments, packed in polypropylene bags $31 \times 36 \mathrm{~cm}$ with thickness of 30 micron sealed hermetically. Three florets of broccoli were taken and placed in carton box at the dimensions of $43 \times 33 \times 12 \mathrm{~cm}$ as one replicate; and stored at $5^{\circ} \mathrm{C}$ and $95 \% \mathrm{RH}$ for 15 days. The sample for each treatment was taken at random in three replications and arranged in a complete randomized design. Samples were evaluated for the changes in the quality parameters at 5, 10 and 15 days during storage.

\section{The obtained data were recorded as follows:}

1- Weight loss percentage: It was calculated from the difference between initial and final weight and expressed as o percentage of the initial fresh weight.

2- Visual appearance: It was determined using score system of $9=$ excellent, $7=$ good, $5=$ fair, $3=$ poor and $1=$ unmarktable. This scale depends on the morphological defects, such as wilted florets, color change of florets.

3- Hue angle: was measuring with (Minolta CR200, Japan) six times per head at harvest time and during the periods of storage.
4- Ascorbic acid content ( as indicator for vit. C.): It was determined (as fresh samples of florets) by titration method using 2, 6 dicloro phenol indophenol as dicribed in Ranganna (1979).

\section{Results and Discussion}

\section{The field experiment}

\section{Morphological characters}

Data presented in Table 2 show clearly the effect of foliar spray with magnesium and iron on plant height, number of leaves and total fresh weight per plant of broccoli. It is obvious that, spraying broccoli plants with either $\mathrm{Mg}$ or $\mathrm{Fe}$ and the combination between them at different tested concentrations had a beneficial effect on all studied vegetative growth parameters compared to the control treatment. In this respect, foliar spray of broccoli plants with $\mathrm{Fe}$ at $100 \mathrm{ppm}$ plus $\mathrm{Mg}$ at $0.5 \%$ or $\mathrm{Fe}$ at $100 \mathrm{ppm}$ plus $\mathrm{Mg}$ at $1.0 \%$ significantly increased all the studied vegetative growth traits compared with other treatments with non significant differences between them except number of leaves per plant during the first season.

As for chlorophyll reading (SPAD) in leaves, the same data in Table 2 show clearly that there were significant differences among foliar spray treatments and the control treatment in total chlorophyll content in broccoli leaves during the first season of growth. On the other hand, no significant effects were recorded among the control and plants sprayed with $\mathrm{Fe}$ at 50 or $100 \mathrm{ppm}$ and magnesium at $0.5 \%$ in the second season of growth.

In this connection, the highest values of chlorophyll reading were recorded as a result of spraying broccoli plants with $\mathrm{Fe}$ at $100 \mathrm{ppm}$ plus $\mathrm{Mg}$ at $1.0 \%(81.89$ and $79.90 \mathrm{SPAD})$ in the $1^{\text {st }}$ and $2^{\text {nd }}$ seasons, respectively, followed by Fe at $100 \mathrm{ppm}$ plus $\mathrm{Mg}$ at $0.5 \%$ and $\mathrm{Fe}$ at $50 \mathrm{ppm}$ plus $\mathrm{Mg}$ at $1.0 \%$ with non significant differences among them. On the other hand, the control plants recorded the lowest values of chlorophyll reading in leaves (71.40 and 71.14 SPAD) in the first and second seasons, respectively.

Previous results revealed that vegetative growth parameters and chlorophyll reading of broccoli plants were increased due to the beneficial effects of magnesium on plant growth which may be attributed to its role as the central atom of the chlorophyll molecule and plays an important non-specific role in the process of phosphate transfer (Allison et al., 2001). Many investigators reported that magnesium application caused increases in plant growth (Ahmed et al., 2011 on cauliflower, Darwesh and Atress 2011 on snow pea and Mohammed et al., 2009 on snap bean). Meanwhile, the promotive effect of iron on growth parameters and chlorophyll reading of broccoli plants may be attributed to that iron is necessary for the biosynthesis of chlorophyll and 
cytochrome, besides the function of iron in the metabolism of chloroplast RNA, leading to increase in the biosynthesis materials (produced and accumulated), consequently, the growth was enhanced (Marschner, 1995). Similar findings with iron foliar application were obtained by Lashkari et al., (2007) on cauliflower, Mansour et al., (2012) on pea and El-Tantawy and Nawar (2013) on broad bean.

\section{Yield and its components}

The results listed in Table 3 indicate the effect of foliar spray with magnesium and iron on yield and its components of broccoli plants expressed as diameter, length, weight and total yield of main floret per feddan. Such results reveal that, there were significant differences due to the tested treatments in both seasons of study on all studied parameters of yield and its components compared to the control treatment. In this connection, foliar application with iron at $100 \mathrm{ppm}$ plus magnesium at $1.0 \%$ significantly increased all studied yield and its components parameters followed by iron at 100ppm plus magnesium at $0.5 \%$ and iron at $50 \mathrm{ppm}$ plus magnesium at $1.0 \%$ with non significant differences among them. The enhancing effect of magnesium on yield and its components may be attributed to its aids in the formation of many compounds, such as sugars, proteins, its regulates the uptake of other plant nutrients, especially phosphorus and it is involved in the translocation and metabolism of carbohydrates (Kiss, 1989). These results are in harmony with those obtained by Mohammed et al., (2009) on snap bean, Ahmed et al., (2011) on cauliflower, Darwesh and Atress (2011) on snow pea.

Meanwhile, the enhancing effect of iron on yield and its components may be due to the increasing in photosynthetic pigments (Table3). Other investigators recorded a similar trend such as Lashkari et al., (2007) on cauliflower, Mansour et $a l$. , (2012) on pea, El-Tantawy and Nawar (2013) on broad bean and Kazemi, (2014) on strawberry.

\section{Chemical constituents of broccoli florets}

Data presented in Table 4 show the effect of foliar spray with magnesium and iron in single form or in a mixture at tested concentrations on chemical constituents of broccoli florets. Such results revealed that there were significant differences due to the tested treatments in both seasons of study on all studied chemical constituents i.e., total nitrogen, iron, magnesium and total crude protein percentage compared to the control treatment except dry matter

Percentage which did not significantly affected by foliar spray with both elements in the two seasons.

In this concern, the highest values of magnesium (ppm), iron (ppm) and nitrogen as well as curd protein percentages were recorded as a result of spraying broccoli plants with $\mathrm{Fe}$ at $100 \mathrm{ppm}$ plus $\mathrm{Mg}$ at $1.0 \%$ followed by $\mathrm{Fe}$ at $100 \mathrm{ppm}$ plus $\mathrm{Mg}$ at $0.5 \%$ with non significant differences between them. On the other side, control plants recorded the lowest values in this respect.

The enhancing effect of magnesium on chemical constituents of broccoli florets may be attributed to that magnesium regulates the uptake of other nutrients, especially phosphorus (Allison et al., 2001). These results are in harmony with those obtained by Mohammed et al., (2009) on snap bean, Ahmed et al., (2011) on cauliflower, Darwesh and Atress (2011) on snow pea. Similar findings with iron foliar application were obtained by Mansour et al., (2012) on pea.

\section{The storage experiment}

\section{Weight loss percentage}

The effect of foliar spraying with magnesium and iron on weight loss percentage of broccoli florets stored at $5 \mathrm{C}^{\circ}$ and $95 \% \mathrm{RH}$ for 15 days was summarized in Table 5. Generally, all broccoli florets obtained from plants treated with iron or magnesium and its combinations effectively reduced the weight loss percentage without any significant differences among them (except florets sprayed with $\mathrm{Fe}$ at $50 \mathrm{ppm}$ in the first season). Such results may be due to the beneficial effects of iron (Lashkari et al., 2007, Mansour et al., 2012 El-Tantawy and Nawar 2013) and magnesium (Kiss, 1989, Mohammed et al., 2009, Ahmed et al., 2011, Darwesh and Atress, 2011) on vegetative growth and chemical compositions of broccoli which in turn maintained the metabolic homeostasis after harvest and reduce dehydration of broccoli florets. On the contrary, broccoli florets obtained from non- sprayed plants (control) recorded the highest significant weight loss percentage in both seasons. With respect to storage period, the same table show an increment in weight loss percentages as the storage period extended. This result may be attributed to the loss of water by transpiration or dry mater by respiration.

The interaction between treatments and storage period was significant in both seasons.

\section{Hue angle}

Broccoli florets consists of an immature floral buds enclosed within chlorophyll-containing sepals, the chlorophyll degradation within these sepals that results in the rapid yellowing of the florets during storage. Ethylene appears to have an important role in regulating the yellowing of sepals after harvest, since chlorophyll loss is associated with the increase in floret ethylene synthesis (Tian et al., 1994; Pogson et al., 1995).

Changes in hue angle values of broccoli florets are good indicator of senescence. As shown in Table 5 non-sprayed broccoli florets (control) exhibited detectable decrease in hue angle values as compared with the other treatments. Spraying broccoli plants with iron and magnesium or its combinations gave 
different statistical effects in hue angle of broccoli florets. Spraying broccoli plants by Fe at $100 \mathrm{ppm}$ plus 0.5 or $1.0 \% \mathrm{Mg}$ maintained dark green color of broccoli florets (higher values of hue angle) without significant differences between them in both seasons, followed by florets that treated with $\mathrm{Fe}$ at $50 \mathrm{ppm}+$ 0.5 or $1.0 \% \mathrm{Mg}$ during the first season. On the other side, no significant effect was occurred among broccoli florets obtained from plants sprayed with Fe at $50 \mathrm{ppm}+\mathrm{Mg}$ at $1.0 \%$ and $\mathrm{Fe}$ at $100 \mathrm{ppm}+0.5$ or $1.0 \% \mathrm{Mg}$ in the second season. Generally, it could be concluded that spraying broccoli with $\mathrm{Fe}$ at $100 \mathrm{ppm}$ +0.5 or $1.0 \% \mathrm{Mg}$ significantly maintained broccoli florets with dark green color and delayed broccoli senescence.

Concerning storage period it is obvious from the given data that the hue angle values of broccoli florets gradually decreased as the storage period extended indicating that broccoli florets turned to slight yellow as the storage period prolonged.

The interaction between the sprayed treatments and storage period was significant in both seasons.

\section{Visual appearance}

Broccoli is highly perishable vegetable with an accelerated senescence which leads to tissue deterioration and loss of nutritional and commercial quality (Page et al., 2001). Higher increase in the weight loss percentage and the higher decrease in hue angle values of broccoli florets were expressed as senescence.

Results tabulated in Table 6 reveal that broccoli florets obtained from plants sprayed with $\mathrm{Fe}$ at $100 \mathrm{ppm}+0.5$ or $1.0 \% \mathrm{Mg}$ displayed attractive appearance (high visual appearance score) for 15 days storage at $5 \mathrm{C}^{\circ}$ and $95 \% \mathrm{RH}$ without significant differences among them, followed by florets sprayed with $\mathrm{Fe}$ at $50 \mathrm{ppm}+0.5$ or $1.0 \% \mathrm{Mg}$ which displayed good appearance without significant effect among them in the two seasons. Such results due to the useful rule of iron and magnesium in reducing weight loss percentage and maintaining broccoli florets with green color during storage. Regarding storage period, it is clear that visual appearance score of broccoli florets gradually decreased as the storage period increased. In general broccoli florets become less acceptable to consume after 15 days from storage at $5 \mathrm{C}^{\circ}$ and $95 \% \mathrm{RH}$ for 15 days. The interaction between the used treatments and storage period was significant in the two seasons.

\section{Ascorbic acid content}

Changes in ascorbic acid contents are presented in Table 6. It may be pointed out that ascorbic acid content in broccoli florets is positively affected by the combinations between the high level of iron and the both level of magnesium as compared to the other treatments.

Treating broccoli plants with $\mathrm{Fe}$ at $100 \mathrm{ppm}$ plus $\mathrm{Mg}$ at 0.5 or $1.0 \% \mathrm{Mg}$ significantly maintained higher ascorbic acid content in broccoli florets during storage as compared with other treatments.

On the other hand, non treated florets (control), and florets treated with the two levels of Fe solely maintained lower ascorbic acid content in both seasons. Moreover, no significant effect was noticed between non treated florets (control) or florets treated with the two Fe levels in the first season. Regarding storage period, it is obvious from the obtained results that ascorbic acid content was dramatically decreased in all tested treatments as the storage period increased. The greatest decrease in ascorbic acid content was noticed at the end of the storage (15 days) in both seasons. The interaction between tested treatments and storage period was significant in both seasons.

\section{Conclusion}

From the previous results of this investigation, it could be concluded that spraying broccoli plants with $\mathrm{Fe}$ at $100 \mathrm{ppm}$ plus $\mathrm{Mg}$ at $1.0 \%$ or $0.5 \%$ significantly enhanced vegetative growth characters, florets chemical constituents of Fe (ppm), Mg (ppm), N and protein percentages, and yield and its components with non significant differences between them. Furthermore, broccoli florets obtained from plants treated with the previous combinations between iron and magnesium exhibited acceptable appearance, fresh green color and higher ascorbic acid content during storage as compared with the control or other treatments during storage at $5 \mathrm{C}^{\circ}$ and $90-95 \% \mathrm{RH}$. 
Table 2. Effect of foliar spraying with iron and magnesium on morphological characters and chlorophyll reading (SPAD) of broccoli plants during $2012 / 2013$ and 2013/2014 seasons

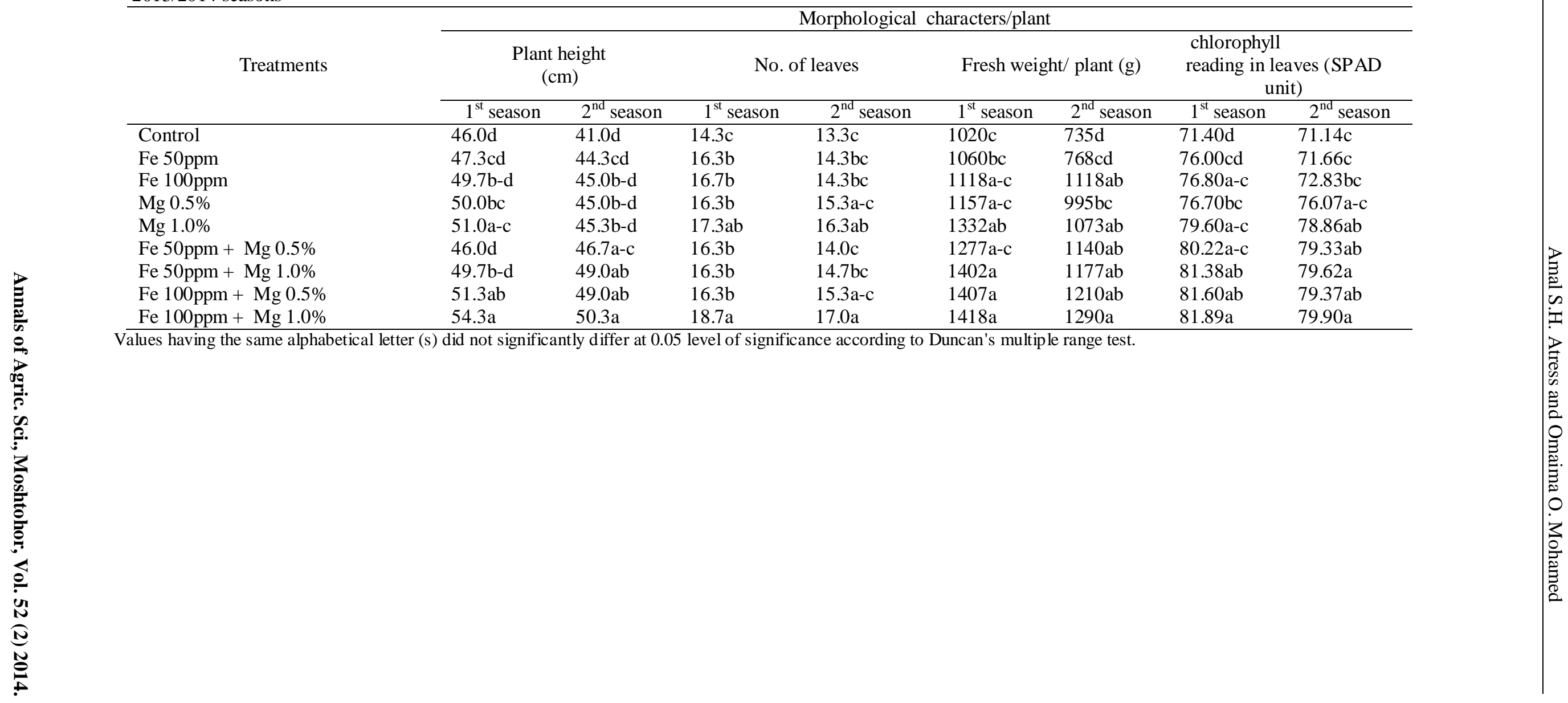


Table 3. Effect of foliar spraying with iron and magnesium on yield and its components of broccoli plants during 2012/2013 and 2013/2014 seasons

\begin{tabular}{|c|c|c|c|c|c|c|c|c|}
\hline \multirow{3}{*}{ Treatments } & \multicolumn{8}{|c|}{ Yield and its components of main florets } \\
\hline & \multicolumn{2}{|c|}{ Diameter $(\mathrm{cm})$} & \multicolumn{2}{|c|}{ Length $(\mathrm{cm})$} & \multicolumn{2}{|c|}{ Weight $(\mathrm{g})$} & \multicolumn{2}{|c|}{ Yield (ton/fed) } \\
\hline & $1^{\text {st }}$ season & $2^{\text {nd }}$ season & $1^{\text {st }}$ season & $2^{\text {nd }}$ season & $1^{\text {st }}$ season & $2^{\text {nd }}$ season & $1^{\text {st }}$ season & $2^{\text {nd }}$ season \\
\hline Control & $20.3 \mathrm{c}$ & $17.7 \mathrm{c}$ & $14.7 \mathrm{bc}$ & $11.3 \mathrm{f}$ & $415.0 \mathrm{~d}$ & $271.7 \mathrm{~d}$ & $4.980 \mathrm{~d}$ & $3.260 \mathrm{~d}$ \\
\hline Fe 50ppm & $21.7 \mathrm{bc}$ & $19.7 b$ & $13.3 \mathrm{c}$ & $11.7 \mathrm{ef}$ & $420.0 \mathrm{~cd}$ & $278.3 \mathrm{~cd}$ & $5.040 \mathrm{~cd}$ & $3.340 \mathrm{~cd}$ \\
\hline $\mathrm{Fe} 100 \mathrm{ppm}$ & $23.0 \mathrm{~b}$ & $21.0 \mathrm{ab}$ & $16.7 \mathrm{a}$ & $15.7 \mathrm{a}$ & $455.0 \mathrm{~b}-\mathrm{d}$ & $315.0 \mathrm{~b}-\mathrm{d}$ & $5.460 \mathrm{~b}-\mathrm{d}$ & $3.780 \mathrm{~b}-\mathrm{d}$ \\
\hline $\operatorname{Mg} 0.5 \%$ & $23.7 b$ & $22.3 \mathrm{a}$ & $15.7 \mathrm{ab}$ & $14.7 \mathrm{ab}$ & $465.0 \mathrm{~b}-\mathrm{d}$ & $371.7 \mathrm{a}-\mathrm{c}$ & $5.580 \mathrm{~b}-\mathrm{d}$ & $4.460 \mathrm{a}-\mathrm{c}$ \\
\hline $\operatorname{Mg} 1.0 \%$ & $26.3 \mathrm{a}$ & $22.7 \mathrm{a}$ & $16.3 \mathrm{ab}$ & $12.7 \mathrm{de}$ & $523.3 \mathrm{a}-\mathrm{d}$ & $400.0 \mathrm{ab}$ & $6.280 \mathrm{a}-\mathrm{d}$ & $4.800 \mathrm{ab}$ \\
\hline $\mathrm{Fe} 50 \mathrm{ppm}+\mathrm{Mg} 0.5 \%$ & $26.3 \mathrm{a}$ & $21.7 \mathrm{a}$ & $16.3 \mathrm{ab}$ & $13.0 \mathrm{~cd}$ & $531.7 \mathrm{a}-\mathrm{c}$ & $381.7 \mathrm{ab}$ & $6.380 \mathrm{a}-\mathrm{c}$ & $4.580 \mathrm{ab}$ \\
\hline $\mathrm{Fe} 50 \mathrm{ppm}+\mathrm{Mg} 1.0 \%$ & $27.7 \mathrm{a}$ & $22.7 \mathrm{a}$ & $17.3 \mathrm{a}$ & $12.3 \mathrm{~d}-\mathrm{f}$ & $545.0 \mathrm{ab}$ & $390.0 \mathrm{ab}$ & $6.540 \mathrm{ab}$ & $4.680 \mathrm{ab}$ \\
\hline $\mathrm{Fe} 100 \mathrm{ppm}+\mathrm{Mg} 0.5 \%$ & $27.7 \mathrm{a}$ & $22.7 \mathrm{a}$ & $15.7 \mathrm{ab}$ & $14.0 \mathrm{bc}$ & $566.7 \mathrm{ab}$ & $415.0 \mathrm{a}$ & $6.800 \mathrm{ab}$ & $4.980 \mathrm{a}$ \\
\hline $\mathrm{Fe} 100 \mathrm{ppm}+\mathrm{Mg} 1.0 \%$ & $28.3 \mathrm{a}$ & $23.0 \mathrm{a}$ & $16.7 \mathrm{a}$ & $13.3 \mathrm{~cd}$ & $583.3 \mathrm{a}$ & $428.3 \mathrm{a}$ & $7.000 \mathrm{a}$ & $5.140 \mathrm{a}$ \\
\hline
\end{tabular}

Values having the same alphabetical letter (s) did not significantly differ at 0.05 level of significance according to Duncan's multiple range test.

Table 4. Effect of foliar spraying with iron and magnesium on chemical constituents of broccoli plants during 2011/2012 and 2012/2013 seasons

\begin{tabular}{|c|c|c|c|c|c|c|c|c|c|c|}
\hline \multirow{3}{*}{ Treatments } & \multicolumn{10}{|c|}{ Chemical constituents of florets } \\
\hline & \multicolumn{2}{|c|}{ Dry matter \% } & \multicolumn{2}{|c|}{ Magnesium (ppm) } & \multicolumn{2}{|c|}{ Iron $(\mathrm{ppm})$} & \multicolumn{2}{|c|}{$\mathrm{N} \%$} & \multicolumn{2}{|c|}{ Total crude protein $\%$} \\
\hline & $1^{\text {st }}$ season & $2^{\text {nd }}$ season & $1^{\text {st }}$ season & $2^{\text {nd }}$ season & $1^{\text {st }}$ season & $2^{\text {nd }}$ season & $1^{\text {st }}$ season & $2^{\text {nd }}$ season & $1^{\text {st }}$ season & $2^{\text {nd }}$ season \\
\hline Control & $11.75 \mathrm{a}$ & $10.22 \mathrm{a}$ & $639 d$ & $643 c$ & $28.7 \mathrm{e}$ & $29.7 \mathrm{c}$ & $1.72 \mathrm{c}$ & $1.79 \mathrm{~b}$ & $10.75 c$ & $11.19 \mathrm{~b}$ \\
\hline $\mathrm{Fe} 50 \mathrm{ppm}$ & $11.98 \mathrm{a}$ & $10.30 \mathrm{a}$ & $642 d$ & $678 \mathrm{c}$ & $34.0 \mathrm{de}$ & $33.7 b c$ & $1.96 \mathrm{a}-\mathrm{c}$ & $2.04 \mathrm{ab}$ & $12.25 \mathrm{a}-\mathrm{c}$ & $12.75 \mathrm{ab}$ \\
\hline $\mathrm{Fe} 100 \mathrm{ppm}$ & $11.82 \mathrm{a}$ & $10.35 \mathrm{a}$ & $647 \mathrm{~d}$ & $680 \mathrm{c}$ & $47.7 \mathrm{ab}$ & $49.3 \mathrm{a}$ & $2.26 \mathrm{a}-\mathrm{c}$ & $2.25 \mathrm{ab}$ & $14.13 \mathrm{a}-\mathrm{c}$ & $14.06 \mathrm{ab}$ \\
\hline $\operatorname{Mg} 0.5 \%$ & $11.95 \mathrm{a}$ & $10.44 \mathrm{a}$ & $795 c$ & $792 b$ & $30.3 \mathrm{de}$ & $30.0 \mathrm{c}$ & $1.83 \mathrm{bc}$ & $1.89 \mathrm{ab}$ & $11.44 \mathrm{bc}$ & $11.81 \mathrm{ab}$ \\
\hline $\operatorname{Mg} 1.0 \%$ & $11.82 \mathrm{a}$ & $11.16 \mathrm{a}$ & $895 \mathrm{ab}$ & $833 b$ & $31.7 \mathrm{de}$ & $33.3 \mathrm{bc}$ & $1.86 \mathrm{bc}$ & $2.01 \mathrm{ab}$ & $11.63 \mathrm{bc}$ & $12.56 \mathrm{ab}$ \\
\hline $\mathrm{Fe} 50 \mathrm{ppm}+\mathrm{Mg} 0.5 \%$ & $11.52 \mathrm{a}$ & $10.74 \mathrm{a}$ & $820 b c$ & $812 b$ & $37.7 \mathrm{~cd}$ & $36.7 b c$ & $2.15 \mathrm{a}-\mathrm{c}$ & $2.19 \mathrm{ab}$ & $13.44 \mathrm{a}-\mathrm{c}$ & $13.69 \mathrm{ab}$ \\
\hline $\mathrm{Fe} 50 \mathrm{ppm}+\mathrm{Mg} 1.0 \%$ & $11.10 \mathrm{a}$ & $10.74 \mathrm{a}$ & $837 \mathrm{bc}$ & $835 b$ & $42.3 b c$ & $40.7 b$ & $2.39 \mathrm{a}-\mathrm{c}$ & $2.28 \mathrm{ab}$ & $14.94 \mathrm{a}-\mathrm{c}$ & $14.25 \mathrm{ab}$ \\
\hline $\mathrm{Fe} 100 \mathrm{ppm}+\mathrm{Mg} 0.5 \%$ & $11.84 \mathrm{a}$ & $10.79 \mathrm{a}$ & $974 a$ & $961 \mathrm{a}$ & $49.7 \mathrm{a}$ & $50.3 \mathrm{a}$ & $2.78 \mathrm{ab}$ & $2.67 \mathrm{ab}$ & $17.38 \mathrm{ab}$ & $16.69 \mathrm{ab}$ \\
\hline $\mathrm{Fe} 100 \mathrm{ppm}+\mathrm{Mg} 1.0 \%$ & $12.55 \mathrm{a}$ & $10.96 \mathrm{a}$ & $983 a$ & $979 \mathrm{a}$ & $51.0 \mathrm{a}$ & $52.3 \mathrm{a}$ & $2.92 \mathrm{a}$ & $2.89 \mathrm{a}$ & $18.25 \mathrm{a}$ & $18.06 \mathrm{a}$ \\
\hline
\end{tabular}


Table 5. Effect of foliar spraying with iron and magnesium on weight loss $\%$ and hue angle of broccoli florets during storage at $5^{\circ}$ and $90-95$ RH $\%$ for 15 days in 2012 2013 and 2013-2014 seasons

\begin{tabular}{|c|c|c|c|c|c|c|c|c|c|c|}
\hline \multirow{3}{*}{ Treatments (T) } & \multicolumn{5}{|c|}{$2012-2013$} & \multicolumn{5}{|c|}{$2013-2014$} \\
\hline & \multicolumn{5}{|c|}{ Storage period (days) } & \multicolumn{5}{|c|}{ Storage period (days) } \\
\hline & 0 & 5 & 10 & 15 & Mean & 0 & 5 & 10 & 15 & Mean \\
\hline \multicolumn{11}{|c|}{ Weight loss (\%) } \\
\hline Control & - & 0.14 & 0.17 & 0.19 & 0.16 & - & 0.18 & 0.19 & 0.25 & 0.20 \\
\hline Fe 50ppm & - & 0.11 & 0.13 & 0.18 & 0.14 & - & 0.13 & 0.14 & 0.21 & 0.16 \\
\hline $\mathrm{Fe} 100 \mathrm{ppm}$ & - & 0.11 & 0.11 & 0.18 & 0.13 & - & 0.12 & 0.14 & 0.21 & 0.15 \\
\hline $\operatorname{Mg} 0.5 \%$ & - & 0.07 & 0.11 & 0.19 & 0.13 & - & 0.09 & 0.13 & 0.20 & 0.14 \\
\hline $\operatorname{Mg} 1.0 \%$ & - & 0.07 & 0.12 & 0.19 & 0.13 & - & 0.09 & 0.12 & 0.21 & 0.14 \\
\hline $\mathrm{Fe} 50 \mathrm{ppm}+\mathrm{Mg} 0.5 \%$ & - & 0.06 & 0.11 & 0.21 & 0.13 & - & 0.05 & 0.14 & 0.23 & 0.14 \\
\hline $\mathrm{Fe} 50 \mathrm{ppm}+\mathrm{Mg} 1.0 \%$ & - & 0.05 & 0.12 & 0.21 & 0.13 & - & 0.06 & 0.13 & 0.22 & 0.14 \\
\hline $\mathrm{Fe} 100 \mathrm{ppm}+\mathrm{Mg} 0.5 \%$ & - & 0.04 & 0.12 & 0.20 & 0.12 & - & 0.06 & 0.13 & 0.22 & 0.13 \\
\hline $\mathrm{Fe} 100 \mathrm{ppm}+\mathrm{Mg} 1.0 \%$ & - & 0.04 & 0.12 & 0.19 & 0.12 & - & 0.06 & 0.12 & 0.21 & 0.13 \\
\hline Mean & - & 0.78 & 0.12 & 0.19 & - & - & 0.09 & 0.13 & 0.21 & - \\
\hline LSD at $0.05 \%$ & & $\mathrm{~T}=0.02$ & $\mathrm{~S}=0.01$ & $\mathrm{~T} \mathrm{X} \mathrm{S}=0.05$ & & & $\mathrm{~T}=0.02$ & $\mathrm{~S}=0.01$ & TX S = 0.05 & \\
\hline \multicolumn{11}{|c|}{ hue angle } \\
\hline Control & 117.28 & 117.09 & 116.53 & 115.30 & 116.55 & 117.82 & 117.49 & 116.07 & 115.17 & 116.64 \\
\hline $\mathrm{Fe} 50 \mathrm{ppm}$ & 119.47 & 117.29 & 116.48 & 115.05 & 117.07 & 118.66 & 118.39 & 115.62 & 115.42 & 117.02 \\
\hline Fe 100ppm & 119.19 & 117.19 & 116.48 & 115.72 & 117.15 & 119.50 & 117.49 & 116.00 & 115.73 & 117.18 \\
\hline $\operatorname{Mg} 0.5 \%$ & 119.99 & 117.46 & 117.17 & 115.60 & 117.55 & 119.01 & 118.21 & 116.44 & 116.22 & 117.47 \\
\hline $\operatorname{Mg} 1.0 \%$ & 120.49 & 119.65 & 117.24 & 116.85 & 118.56 & 119.76 & 119.09 & 117.22 & 115.44 & 117.87 \\
\hline $\mathrm{Fe} 50 \mathrm{ppm}+\mathrm{Mg} 0.5 \%$ & 120.22 & 119.56 & 119.32 & 117.83 & 119.23 & 119.24 & 118.01 & 117.46 & 116.64 & 117.83 \\
\hline $\mathrm{Fe} 50 \mathrm{ppm}+\mathrm{Mg} 1.0 \%$ & 120.00 & 119.80 & 119.11 & 118.51 & 119.35 & 119.93 & 118.74 & 117.77 & 117.63 & 118.52 \\
\hline $\mathrm{Fe} 100 \mathrm{ppm}+\mathrm{Mg} 0.5 \%$ & 122.30 & 120.80 & 119.10 & 118.39 & 120.15 & 119.59 & 119.53 & 118.10 & 116.72 & 118.49 \\
\hline $\mathrm{Fe} 100 \mathrm{ppm}+\mathrm{Mg} 1.0 \%$ & 122.27 & 120.33 & 119.81 & 118.63 & 120.26 & 120.22 & 119.60 & 118.80 & 118.04 & 119.16 \\
\hline Mean & 120.13 & 118.80 & 117.91 & 116.87 & - & 119.30 & 118.50 & 117.05 & 116.33 & - \\
\hline LSD at $0.05 \%$ & & $\mathrm{~T}=0.73$ & $\mathrm{~S}=0.48$ & $\mathrm{~T} \mathrm{X} \mathrm{S}=1.46$ & & & $\mathrm{~T}=0.73$ & $\mathrm{~S}=0.49$ & $\mathrm{TX} \mathrm{S}=1.47$ & \\
\hline
\end{tabular}

$\mathrm{S}=$ Storage period 
Table 6. Effect of foliar spraying with magnesium and iron on visual appearance, and ascorbic acid content (mg/100g FW) of broccoli florets during storage at $5^{\circ}$ and 90-95 RH\% for 15 days in 2012-2013and 2013-2014 seasons

\begin{tabular}{|c|c|c|c|c|c|c|c|c|c|c|}
\hline \multirow{3}{*}{ Treatments (T) } & \multicolumn{5}{|c|}{$2012-2013$} & \multicolumn{5}{|c|}{$2013-2014$} \\
\hline & \multicolumn{5}{|c|}{ Storage period (days) } & \multicolumn{5}{|c|}{ Storage period (days) } \\
\hline & 0 & 5 & 10 & 15 & Mean & 0 & 5 & 10 & 15 & Mean \\
\hline \multicolumn{11}{|c|}{ Visual appearance score* } \\
\hline Control & 9.00 & 7.33 & 5.66 & 3.00 & 6.25 & 9.00 & 7.00 & 5.00 & 3.00 & 6.00 \\
\hline Fe 50ppm & 9.00 & 8.00 & 6.00 & 3.33 & 6.58 & 9.00 & 7.33 & 5.00 & 3.00 & 6.08 \\
\hline $\mathrm{Fe} 100 \mathrm{ppm}$ & 9.00 & 8.00 & 6.00 & 3.66 & 6.66 & 9.00 & 7.00 & 5.00 & 3.33 & 6.08 \\
\hline $\operatorname{Mg} 0.5 \%$ & 9.00 & 8.00 & 6.66 & 5.00 & 7.16 & 9.00 & 8.00 & 6.66 & 4.66 & 7.08 \\
\hline $\operatorname{Mg} 1.0 \%$ & 9.00 & 8.33 & 7.00 & 6.00 & 7.58 & 9.00 & 8.00 & 7.00 & 5.00 & 7.25 \\
\hline $\mathrm{Fe} 50 \mathrm{ppm}+\mathrm{Mg} 0.5 \%$ & 9.00 & 9.00 & 7.33 & 7.00 & 8.08 & 9.00 & 9.00 & 7.00 & 6.00 & 7.75 \\
\hline $\mathrm{Fe} 50 \mathrm{ppm}+\mathrm{Mg} 1.0 \%$ & 9.00 & 9.00 & 7.33 & 7.00 & 8.08 & 9.00 & 9.00 & 7.00 & 6.66 & 7.91 \\
\hline $\mathrm{Fe} 100 \mathrm{ppm}+\mathrm{Mg} 0.5 \%$ & 9.00 & 9.00 & 8.66 & 7.33 & 8.50 & 9.00 & 9.00 & 8.66 & 7.00 & 8.41 \\
\hline $\mathrm{Fe} 100 \mathrm{ppm}+\mathrm{Mg} 1.0 \%$ & 9.00 & 9.00 & 8.66 & 7.33 & 8.50 & 9.00 & 9.00 & 8.66 & 7.00 & 8.41 \\
\hline Mean & 9.00 & 8.40 & 7.03 & 5.51 & - & 9.00 & 8.14 & 6.66 & 5.07 & - \\
\hline LSD at $0.05 \%$ & & $\mathrm{~T}=0.27$ & $\mathrm{~S}=0.18$ & $\mathrm{TX} \mathrm{S}=0.54$ & & & $\mathrm{~T}=0.20$ & $\mathrm{~S}=0.13$ & $\mathrm{TX} \mathrm{S}=0.41$ & \\
\hline \multicolumn{11}{|c|}{ Ascorbic acid content $(\mathrm{mg} / 100 \mathrm{~g} F W)$} \\
\hline Control & 122.18 & 112.50 & 81.50 & 65.63 & 95.45 & 119.45 & 109.00 & 81.00 & 65.63 & 93.77 \\
\hline Fe 50ppm & 122.50 & 114.45 & 85.00 & 69.25 & 97.80 & 121.30 & 111.00 & 83.50 & 66.25 & 95.51 \\
\hline $\mathrm{Fe} 100 \mathrm{ppm}$ & 122.56 & 114.85 & 85.38 & 69.42 & 98.05 & 121.43 & 111.10 & 84.00 & 66.58 & 95.78 \\
\hline $\operatorname{Mg} 0.5 \%$ & 123.12 & 115.50 & 85.82 & 72.38 & 99.20 & 121.50 & 112.50 & 85.19 & 68.76 & 96.99 \\
\hline $\operatorname{Mg} 1 \%$ & 123.45 & 116.78 & 86.15 & 72.86 & 99.79 & 121.50 & 112.50 & 85.23 & 69.50 & 97.18 \\
\hline $\mathrm{Fe} 50 \mathrm{ppm}+\mathrm{Mg} 0.5 \%$ & 123.45 & 117.72 & 86.55 & 73.28 & 100.25 & 122.33 & 115.31 & 88.33 & 70.25 & 99.06 \\
\hline $\mathrm{Fe} 50 \mathrm{ppm}+\mathrm{Mg} 1.0 \%$ & 123.50 & 117.83 & 94.30 & 74.25 & 102.47 & 123.16 & 115.33 & 88.90 & 70.25 & 99.41 \\
\hline $\mathrm{Fe} 100 \mathrm{ppm}+\mathrm{Mg} 0.5 \%$ & 123.72 & 119.00 & 100.25 & 75.00 & 104.50 & 123.37 & 116.16 & 94.15 & 72.50 & 101.54 \\
\hline $\mathrm{Fe} 100 \mathrm{ppm}+\mathrm{Mg} 1.0 \%$ & 123.95 & 119.35 & 100.41 & 75.17 & 104.72 & 123.41 & 116.16 & 94.45 & 73.20 & 101.80 \\
\hline Mean & 123.16 & 116.43 & 89.49 & 71.91 & - & 121.94 & 113.23 & 87.19 & 69.21 & - \\
\hline LSD at $0.05 \%$ & & $\mathrm{~T}=0.59$ & $\mathrm{~S}=0.39$ & $\mathrm{TX} \mathrm{S}=1.19$ & & & $\mathrm{~T}=0.38$ & $\mathrm{~S}=0.25$ & $\mathrm{TX} \mathrm{S}=0.77$ & \\
\hline *Score: & & $7=$ Good & & 5=Fair, & & & $1=\mathrm{Unn}$ & narketable. & & \\
\hline
\end{tabular}




\section{References}

Ahmed, M. E., A. A. Elzaawely and M. B. El-Sawy (2011): Effect of the foliar spraying with Molybdenum and Magnesium on vegetative growth and curd yields in cauliflower (Brassica oleraceae var botrytis L.) World J. Agric. Sci. 7(2):149-156.

Allison, M. F., J. H. Fower and E. J. Allen (2001): Factors affecting the magnesium nutrition of potatoes (Solanum tuberosum L.). J.Agric. Sci. Cambridge., 137:397-409.

Bremner, J.M. and C.M. Mulvaney. 1982. Total nitrogen. In [Page, A.L., R.H. Miller, and D.R. Keeney] (Eds). Methods of Soil Analysis, Part 2 Amer. Soc. Agron. Madison. WI-W.S.A. p. 595624.

Brittenham, G. M. (1994): New advances in iron metabolism, iron deficiency and iron overload. Current Opinion in Hematology, 1, 549-556.

Chapman, H.D. and F. Pratt (1982): " Methods Of Soil Analysis”. Part 2 A.S.S. Madison wiscoasin.

Darwesh, F. M. A. and A. S. H. Atress (2011). Effect of spraying with potassium and magnesium on yield, quality and storability of snow pea (Pisum sativum var macrocarpon), J. of Appl. Sci. Res., 26(12): 312-327.

Duncan, B. D. 1958. Multiple range and mlultiple Ftest Biometrics. 11:1-42.

El-Tantawy, E.M. and D. A. S. Nawar (2013): Nodulation, growth, photosynthetic pigments and yield of broad bean plants (Vicia faba L.) as affected by nitrogen source, Rhizobium inoculation and iron foliar application. J. Appl. Sci. Res., 9(1): 974-987.

El-Tantawy, E.M. and M. I. Mahmoud (2013): Effect of nitrogen source, Rhizobium inoculation and foliar spray with iron on plant growth, pod characters and yield of broad bean plants (Vicia faba L.). Hortscience J. Suez Canal Univ., 1: 203 210.

Gad, N. and M.R. Abd El-Moez (2011): Broccoli growth, yield quantity and quality as affected by cobalt nutrition. Agric. Biol. J. N. Am., 2 (2): 226-231.

Hasperue, J.H., A. R. Chaves and G.A. Martinez, (2011): End of day harvest delays postharvest senescence of broccoli florets. Postharvest Bio. and Technol., 59: 64-70.

Havlin, J.L., J.D. Beaton, S.L. Tisdale and W.L. Nelson (1999): Soil Fertility and Fertilizers-An introduction to nutrient management 6th Ed. Prentice Hall, New Jersey. Res., J. of Agric. Biol. Sci., 4(6): 717-724.

Huber,D.J., (1987): Postharvest senescence: an introduction to the symposium. HortScience 22: 853-859.

Kazemi, M. (2014): influence of foliar application of iron, calcium and zinc sulfate on vegetative growth and reproductive characteristics of strawberry cv. 'pajaro'. Trakia J. Sci., 12 (1): 21 26.

King G.A, S.C. Morris., (1994a): Pysiological changes of broccoli during early postharvest senescence and through the preharvest/ postharvest continuum. J. Am .Soc. Hort. Sci, 119: 270-275.

King G.A., S.C. Morris, (1994b): Early compositional changes during postharvest senescence of broccoli. J Am Soc Hort.Sci 119: 1000-1005.

Kiss, S.A., (1989): Effect of magnesium on the anion uptake of plant. Acta Agronom Hung., 38: 23-29.

Lashkari, C. O., A. N. Makwana and M. A.Meman (2007): Effect of zinc and iron on growth and yield of cauliflower (Brassica oleracea var. Botrytis Linn.) cv. Snowball-16. Asian J. Horti., 2 (2): 277-279.

Mansour, N. T. S., D. M. Mostafa and W. M. Abd El-Hakim (2012): Effect of potassium dissolving bacteria and foliar application with some microelements on growth, yield and quality of pea plant under sandy soil conditions. Zagazig J. Agric. Res., 39 (5): 837-848.

Marschner, H. (1995): Mineral nutrition of higher plants, $2^{\text {nd }}$ ed. Academic press, New York, USA.

Mengel, K. and E. A. Kirkby (1987): Principles of plant nutrition. $4^{\text {th }}$ ed. International Potash Institute, Bern, Switzerland.

Mohammed, O. O., H. M. Arisha, A. Bardisi and R. I. El-Bassiouny (2009): Effect of foliar spray with $\mathrm{Ca}, \mathrm{Mg}$ and vitamin $\mathrm{B}_{1}$ on the productivity and storability of snap bean grown in sandy soil. Zagazig J. Agric. Res., 36(1):41-62.

Page, T., G. Griffiths,V. BuchananWollaston,(2001):Molecular and biochemical characterization of postharvest senescence in broccoli. Plant Physiol.125: 718-727.

Peterburgski, A.V. (1968): Hand Book of Agronomic Chemistry. Kolas publishing House, Moscow, (in Russian), pp. 29-86.

Pogson, B.J, C.G. Downs, K.M. Davies,(1995):Differential expression of two 1aminocyclopropane-1 carboxylic acid oxidase genes in broccoli after harvest. Plant Physiol.108: 651-657.

Ranganna, S. (1979): Manual of analysis of fruit and vegetable products. Central food Technological Research Institute. Ph.D. Puplished by Tata McGraw Hil Publishing Company Limited, 12/4 Asaf Ali Road, New Delhi 110002, and printed at Raj Bandhu Industrial Company, C-61, May a puri, phase 11, New Delhi, 1100064.

Rushing, J.W. (1990): Cytokinins affect respiration, ethylene production, and chlorophyll retention of packaged broccoli florets. HortScience 25: 88-90

Schouten, R.E, X. Zhang, J.A. Verschoor, E.C. Otma, L.M.M., Tijskens, O., Van Kooten. (2009): Development of colour of broccoli heads as affected by controlled atmosphere storage and 
temperature. Postharvest Biology and Technology 51: 27-35.

Snedecor, G. W. and W. G. Cochran (1980): Statistical Methods. $7^{\text {th }}$ Ed. The Iowa State Univ., Press, Amer., Iowa, USA.

Tian, MS, C.G. Downs, R.E, Lill, G.A. King. (1994):

A role for ethylene in the yellowing of broccoli after harvest. J. Am. Soc. Hort. Sci, 119: 276281.

Tolba, M.S., (2005): Influence of different nitrogenous and potassic fertilization levels on vegetative growth, heads yield and chemical composition of broccoli. M.Sc. Thesis, Cairo University. 


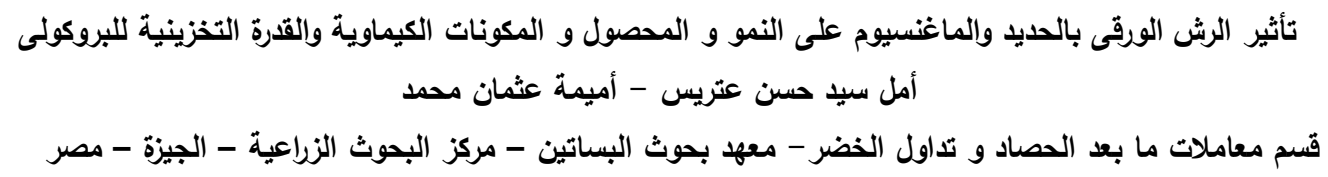

أجريت هذه الدراسة فى المزرعة البحثية بمحطة بحوث البساتين بالقصاصين بمحافظة الإسماعلية مصر ومعمل قسم بحوث تداول

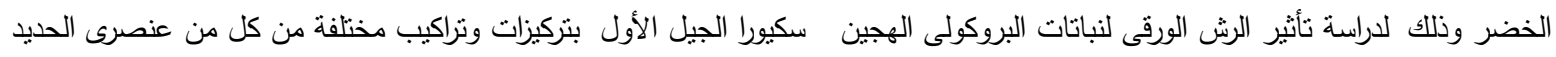

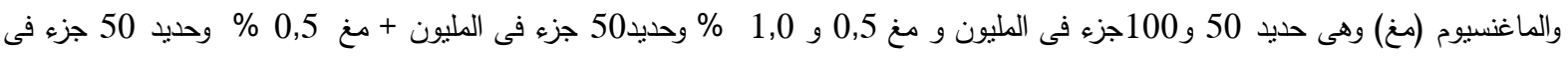

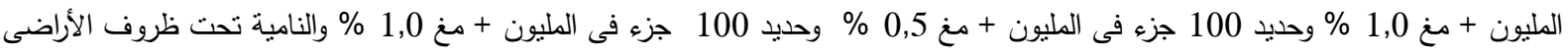

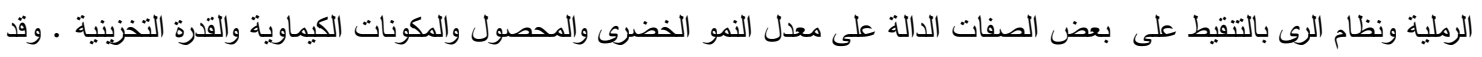
أوضحت النتائج أن الرش الورقى لنباتات البروكولى بالحديد بتركيز 100 جزء فى المليون +

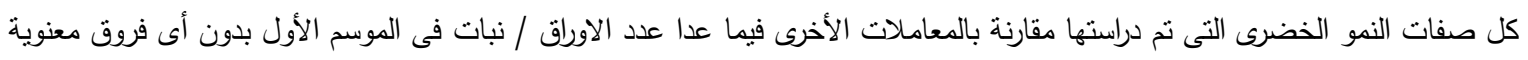

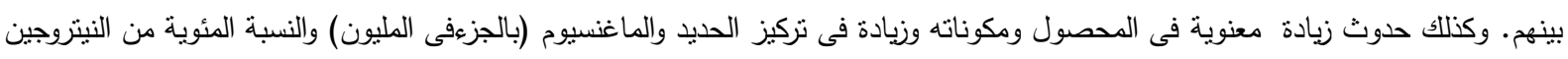

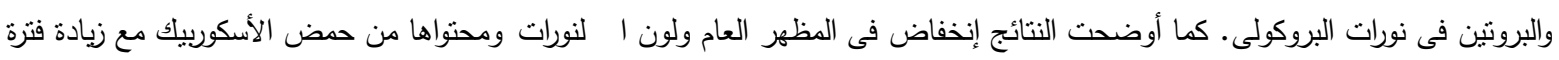

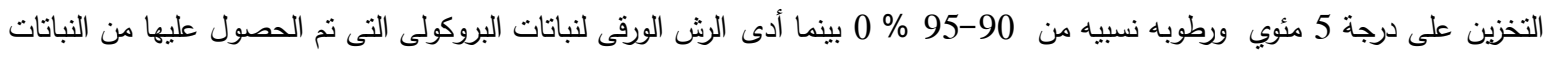

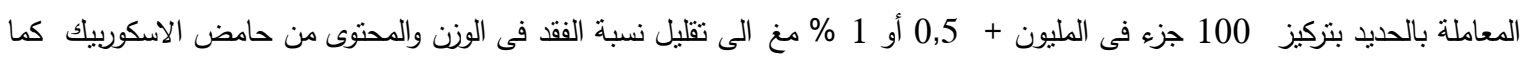
احتفظت نورات البروكولى بمظهر جيد لمدة 15 يوم من التخزين. 